\title{
PATRIOTIC EDUCATION OF FUTURE TEACHERS OF GEOGRAPHY BY MEANS OF TOURIST AND LOCAL HISTORY WORK
}

\author{
Maksiutov Andrii, $\mathrm{PhD}$ in Pedagogical Sciences, Associate Professor, Department of \\ Geography and Methods of Teaching, Pavlo Tychyna Uman State Pedagogical University. \\ ORCID: 0000-0002-5486-634X \\ E-mail: andriy.maksyutov@udpu.edu.ua
}

\begin{abstract}
The structural and functional aspects of patriotic education of future teachers of geography by means of tourism and local history work are substantiated in the article that involves the interaction of its elements (value-driven, motivational, cognitive, personal and practical); principles (humanization, democratization, conformity to nature, conformity to culture and educational advisability), forms, methods, means and functions of tourism and local history work. The latter were proved to be a compulsory element of future teachers of geography practical training. The analysis of the literary sources in which the question of patriotic education of future teachers of geography youth by means of tourism and local history work is revealed.

Keywords: education, patriotic education, scientific problem, content of patriotic upbringing, pedagogical conditions of patriotic upbringing, patriotic upbringing, tourist and local history work, higher education institution, future teacher of geography, components and results of patriotic upbringing.
\end{abstract}

\section{ПАТРІОТИЧНЕ ВИХОВАННЯ МАЙБУТНІХ УЧИТЕЛІВ ГЕОГРАФІЇ ЗАСОБАМИ ТУРИСТСЬКО-КРАЕЗНАВЧОЇ РОБОТИ}

Максютов Андрій, кандидат педагогічних наук, доцент, доцент кафедри географії та методики їі навчання, Уманський державний педагогічний університет імені Павла Тичини.

ORCID: 0000-0002-5486-634X

E-mail: andriy.maksyutov@udpu.edu.ua

У статті теоретично обтрунтовано структурно-функиіональні аспекти патріотичного виховання майбутніх учителів географії засобами туристсько-краєзнавчої роботи, що відображає взаємодію його компонентів; принципів, форм, методів, засобів $i$ функиій туристсько-краєзнавчої діяльності. 3'ясовано та обтрунтовано, щзо туристсько-краєзнавча діяльність є обов'язковим елементом практичної підготовки майбутнього вчителя географії. Встановлено, щзо в сучасних умовах розбудови національної системи освіти патріотичне виховання $\epsilon$ актуальним засобом формування позитивних мотивів навчально-пізнавальної діяльності покоління, щчо підростає. Доведено, щчо туристсько-краєзнавча робота - це активний вид навчально-пізнавальної діяльності, щзо сприяє моральному, фізичному, трудовому, естетичному, екологічному вихованню особистості, розширює світогляд $i$ формує стійку життєву позииію.

Виявлено, щу туристсько-краєзнавча робота у закладах вищої освіти реалізується через упровадження та викладання відповідних навчальних дисииплін, щзо розкривають поняття 
краєзнавчої та туристичної роботи. Встановлено, щзо патріотичне виховання студентівгеографів закладів вищої освіти здійснюється шляхом використання різних видів навчальної та наукової діяльності із застосування різноманітних методів та технологічних прийомів у межах аудиторної та позааудиторної роботи.

Виконано аналіз літературних джерел, у яких розкривається питання патріотичного виховання студентської молоді засобами туристсько-краєзнавчої діяльності. Висвітлено окремі суперечності у підготовці майбутніх учителів географії. Розкрито перспективні питання, щэо будуть вирімені при виконанні цьього дослідження, та практичне значення розв'язання иієї проблеми для освітянської сфери.

Доведено, що актуальною науковою проблемою є не лише розкриття змісту патріотичного виховання як соціальної проблеми, але $i$ перевірка ефективності педагогічних умов патріотичного виховання майбутніх учителів географії у процесі туристсько-краєзнавчої роботи.

Ключові слова: освіта, патріотичне виховання, наукова проблема, зміст патріотичного виховання, педагогічні умови патріотичного виховання, патріотична вихованість, туристськокраєзнавча діяльність, заклад вищої освіти, майбутній учитель географії, компоненти та результати патріотичного виховання.

In the current situation, when the national system of education is being developed, patriotic education is a powerful tool of positive influence on educational and cognitive activities of the younger generation. Tourism and local history work is the type of educational and cognitive activities that triggers ethical, physical, labour, aesthetic, and environmental education of young people as well as widens their horizon and develops their personality and principles. Tourism and local history work in pedagogical universities is implemented through teaching and learning process via incorporation of certain courses in the curriculum that introduce the initial idea of tourism and local history work. Patriotic education of university students majoring in Geography is organized through various types of academic and research activities via different methods of education during face-to-face classes as well as via various extra-curricular activities. Tourism and local history work is a compulsory element of practical training of the future Geography teacher. That is why this research on the current situation of patriotic education of prospective Geography teachers is an extremely important task today.

The relevance of the problem of patriotic education of students - future teachers of Geography was proved via profound analysis of the existing resources that contain research of patriotic education of students through tourism and local lore activity. Some contradictions in the training process of future teachers of Geography are highlighted.

Theoretical and methodological aspects of patriotic education are up-to-date and extremely important research subjects for nowadays scientists. These aspects appeared in the works of famous Ukrainian and foreign researchers, philosophers, historians and educators, such as: Voronkov O.M. [1, p. 18], Krachylo M.P. [2, p. 190], Krul V.P. [3, p. 107], Oboznyi V.V. [4, p. 265], Timets O.V. [5, p. 194], Petranivskyi V.L., Rutynskyi M.I. $[6$, p. 575] etc.

In particular, Voronkov O. M. explored ways to implement patriotic education through the concept of national-patriotic education of student youth. In his opinion, the priority is to improve the legal framework for patriotic education of youth [1, p. 18].

Krachylo M. P. covered the theoretical, methodological, organizational and legal principles of tourism management; studied the basic concepts of tourism, components of the tourism industry; analyzed the factors of functioning and development of tourist 
organizations, as well as the main management functions and problems of tourism management, studied the territorial structure of the tourism industry [2, p. 190].

Krul V.P. studied the monuments of defense architecture as a basis for the development of cultural and cognitive tourism, the formation of Ukrainian geographical local lore, geographical aspects of archaeological tourism, characteristics of cultural and historical landscapes, the territorial hierarchical structure of cultural and historical recreational resources [3, p. 107].

Oboznyi V. V. researched: theoretical aspects of educating students in the process of tourism - local history activities; the importance of local history work and tourism in the educational process of pedagogical university; geography - local history training of specialists in the conditions of reforming higher pedagogical education; scientific bases of tourist - geographical local history and training of specialists for the sphere of tourism in higher education institutions. Developed the "Concept of local history education and upbringing"; "Standard of geographical and local history education and tourist training of a specialist in a pedagogical university"; "The concept of local history training of tourism managers in a pedagogical university"; developed and implemented an organizational and methodological system of local history education, upbringing and professional orientation of talented young people in the system of the Small Academy of Sciences of Ukraine; system of tourist and local history training of students of geographical specialties of pedagogical universities [4, p. 265].

Timets O. V. researched: the processes of preparation of future teachers of geography and biology for local history and tourism work with students; theory and practice of formation of professional competence of the future teacher of geography in the process of professional training; tourist and local history work in a higher pedagogical educational institution: organizational and methodological aspects; organization of local history and tourist work with pupils and students; professional training of a future teacher of geography: the relationship of cognitive, operational and personal components of his professional competence; psychological and pedagogical factors of professional development of a geography teacher in the system of continuing education [5, p. 194].

Petranivskyi V. L. substantiated the conceptual and theoretical foundations of tourist and local history work of Ukraine. He dealt with the problem of determining the objectsubject essence of tourist and local history activities, theoretical foundations and methodological arsenal of local history work research. Using the principle of local history analysis, he characterized the national recreational and tourist potential. In developing the theoretical and methodological provisions of tourist local history work, the author used modern developments in geographical science, tourism and balneology, regional economics and the location of productive forces, management of services and other sciences. The author gave a definition of local history work as a pedagogical concept, highlighting the socioeconomic, educational and methodological aspects. His scientific achievements are used by higher education institutions that are preparing to work in the field of tourism or local history education, teachers of higher educational institutions, teachers and active members of public local history societies, as well as anyone interested in tourism development in their homeland [6, p. 575].

Rutynskyi M. Y. researched: the place of tourism geography in the structure of geographical science, its epistemological essence and the main interdisciplinary directions of

\section{ISSN 2307-4906}


development; main features of international tourism business development; rural green tourism; trends in the development of green tourism in the resort and recreational systems of the Ukrainian Carpathians; castle tourism in Ukraine; geography of tourism: state, vectors and current trends in the XXI century; geography of religious tourism in Ukraine; socio-economic significance of rural green tourism in the context of modern priorities of rural development of Ukraine; ethno-festival tourism: theoretical principles and ethno-geographical aspects of the organization [6, p. 575].

Education of patriotically conscious generation, a new generation of Geography teachers in an independent Ukraine is rather complex process that depends not only on the general tendencies in Pedagogy, but also on political climate in the country as well as social and economic situation.

In general, the process of education is a purposeful influence on the development of personality of the student that leads to obtaining social experience by this individual, familiarizing them with national achievements of people who live in the same country. Moreover, education can be defined as a continual and durable system of educational measures aimed at forming a comprehensive and harmoniously developed personality.

The process of education of personality depends on objective and subjective factors. Objective factors include the way of state development, building market economy, resuming national traditions, influence of the society and so on.

Subjective factors are as follows: influence of family and non-governmental organizations, educational activities of universities, and mass media. Therefore, the education of future teachers of Geography through tourism and local history activities requires immediate updating of the theoretical and methodological foundations of patriotic and ethical education. The educational process in universities is targeted at adults. Therefore, the current research problem is not only to uncover the content of patriotic education as a social problem, but also to check the effectiveness of pedagogical conditions of patriotic education of future teachers of Geography through tourism and local history activities [7, p. 28].

The content of patriotic education of future teachers of Geography through tourism and local history activity includes familiarizing them with basic methods of patriotic education of the younger generation in Geography course; as well as giving them an opportunity to master practical skills in organizing in-class and extra-curricular work. The main ways of improving the content of training the students - future teachers of Geography are as follows: refining professional training of the future Geography teachers; expanding the forms of research work and self-study activities in the framework of different courses, introducing the local lore principle in the system of youth training, developing practical skills in tourism and local history activities, etc. Well thought out combination of tools, forms and methods of work will help to achieve the stated goal. It is worth mentioning that the appropriate methods will be implemented through the appropriate forms of work that they include.

The structure of patriotic education of students - future Geography teachers consists of the following elements:

Value-driven element that identifies the system of patriotic values that are included into the culture and demonstrate the values of independent constitutional state, culture of its people, traditions, customs, inviolability of the motherland, conscious attitude to own patriotic responsibility. 
Motivational element involves students' identification of relevant socially significant and personal motives. The motive for good behavior appears to the full extent when learners face some meaningful activities they are expected to do that are combined with incentives. Forming motives and triggering motivation for creative self-development of the learners is a responsible and important task of the educator. Deep, strong, emotionally-colored and meaningful motives ensure the efficiency of the educator's activities and trigger creative selfdevelopment of every learner [9, p. 542]. The social motive to do one's civic duty is the main motive of student patriotic education. It should be mentioned that the local history activity as a part of professional training of the future Geography teacher includes learning and mastering the skills that will ensure the implementation of motivational element.

Cognitive element is targeted at the development of students' patriotic awareness. It is a set of ideas, concepts, judgments and values that enrich students. Young people should consider themselves to be a part of civil society, understand their importance and their role in establishing and building independent and sovereign Ukraine. This component should be consistent with the overall purpose of education in Ukrainian society - creating a harmoniously developed and socially active personality with research outlook, ethical principles, who wants and is able to work for the benefit of Ukraine, who is healthy and wise. One of the most important issues of the content of education in contemporary Ukrainian society is the opportunity for implementation of the following requirements: ensuring the forming the personality who identifies himself or herself as a citizen of Ukraine; taking into account the real possibilities of the educational process of certain educational systems; ensuring comprehensive and harmonious development of personality; developing and selfdeveloping of the learners; preparing the citizens of Ukraine for future creative activities and forming their opinions and beliefs.

Personal element is based on a personality-oriented approach, which includes psychological and pedagogical analysis, awareness of the features of every student; choosing the content of education taking into account individual traits of the learners; flexibility of forms and methods of education, etc.

Practical element includes practical training of students (organization of local and tourist student associations; participation in tourism competitions; performance of expeditionary research; development of different routes). This component is one of the main components of the educational process and it has two aspects: specific actions and operations of the educator that he or she performs on a daily basis when communicating with the learners; actions, behavior of the learner in the process of mastering spiritual knowledge, forming ethical skills, habits and abilities.

The process of education goes in the following way: involving the learners in the system of relations of all subjects of educational process; acquiring and improving the whole complex of professional, national and conventional values; practical implementation in everyday activities and carving them at a subconscious level; effective influence of this behavior on the way of living, identifying life values; forming and developing motivation for constant self-development.

In addition, when organizing the activities of students, it is necessary to use such means of influence that contribute to the formation of their awareness (knowledge, attitudes, beliefs), conscious attitude to what they do; cover the emotional-willed sphere of personality and improve their behavior that in their combination are the foundation of patriotic education. 
The result of patriotic education should be carving the following things in minds and feelings of the learner: patriotic values, beliefs, respect to the cultural and historical past, forming ethnic and national identity, dedication to the motherland, state, land and people, who live there, recognition of the spiritual unity of all regions of Ukraine, common cultural heritage and future: also patriotic education should lead to upbringing a happy and not indifferent person.

Thus, the results of patriotic education of students - future Geography teachers should be as follows:

- developing respect to the Constitution of Ukraine, laws of Ukraine and state symbols;

- developing awareness of the correlation between individual freedom, human rights and learners' civil responsibility;

- acquisition of patriotic experience by the students and readiness for active participation in the processes of state formation, responsibility and ability to determine the forms and ways of their participation in the life of civil society;

- formation of ethnic and national identity, dedication to the native land, state, motherland and people;

- implementation of humanistic morality, cultivation of the best features of the Ukrainian mentality - diligence, freedom, fairness, kindness, integrity, caring attitude to nature.

Analyzing the situation with patriotic education of future teachers of Geography through tourism and local history activity, we can conclude that this is a complex, systematic and purposeful activity of universities and other social institutions aimed at forming learners' high patriotic awareness, dedication to the Motherland and people, readiness for performing civic and constitutional duty and defending national interests, integrity, independence of the Ukraine, promoting the establishment of a legal, democratic and independent state.

In connection with the growing scale and prospects of social development of our state, with economic and political changes taking place in our society, taking into account the moral and spiritual interests of all segments of the population, the growth of national identity requires a comprehensive strengthening of patriotism teachers of Geography.

The study does not cover all aspects of this multifaceted problem. Further scientific research can be aimed at studying the effectiveness of the complex impact of psychological and pedagogical disciplines of higher education on the development of the spiritual world of the individual, their educational and developmental potential, compliance with the continuity between them.

\section{СПИСОК ВИКОРИСТАНИХ ДЖЕРЕЛ}

1. Воронков О. М. Про туризм у шкільній освіті й вихованні. Краєзнавство. Географія. Туризм. 2005. № 20. C. 18-22.

2. Крачило М. П. Краєзнавство і туризм : навч. посіб. Київ: Вища школа, 1994. 190 с.

3. Круль В. П. Краєзнавство: історична географія. Чернівці: ЧДУ, 1999. 107 с.

4. Національна система виховання: концепція / Міністерство народної освіти України. Київ: Либідь, $1991.28 \mathrm{c}$.

5. Обозний В. В. Краєзнавство : навч. посіб. Київ: ТОВ «Міжнародна фінансова агенція», 1997. 265 с.

6. Петранівський В. Л., Рутинський М.Й. Туристичне краєзнавство : навч. посіб. / за ред. Ф. Д. Заставного. Київ: Знання, 2006. 575 с. 
7. Сухомлинська О. В. Виховання. Педагогічний словник / за ред. М. Д. Ярмаченка. Київ: Педагогічна думка, 2001. С. 85.

8. Тімець О. В., Комар В. П. Організація краєзнавчо-туристської роботи з учнівською та студентською молоддю. Умань: Алмі, 2005. 194 с.

9. Фіцула М. М. Педагогіка: навч. посіб. Київ : Академія, 2000. 542 с.

10. Ярмаченко М. Д. Патріотизм. Педагогічний словник / за ред. М. Д. Ярмаченка. Київ: Педагогічна думка, 2001. С. 356.

\section{REFERENCES}

1. Voronkov, O. M. (2005). Pro turyzm u shkilnii osviti i vykhovanni. Kraieznavstvo. Heohrafiia. Turyzm. 20. 18-22 [in Ukrainian].

2. Krachylo, M. P. (1994). Kraieznavstvo i turyzm. Kyiv: Vyshcha shkola [in Ukrainian].

3. Krul, V. P. (1999). Kraieznavstvo: istorychna heohrafiia. Chernivtsi: ChDU [in Ukrainian].

4. Natsionalna systema vykhovannia: kontseptsiia (1991). Kyiv: Lybid [in Ukrainian].

5. Oboznyi, V. V. (1997). Kraieznavstvo. Kyiv: Mizhnarodna finansova ahentsiia [in Ukrainian].

6. Petranivskyi, V. L., Rutynskyi, M. Y., \& Zastavnyi, F. D. (Ed.). (2006). Turystychne kraieznavstvo. Kyiv: Znannia [in Ukrainian].

7. Sukhomlynska, O. V. (2001). Vykhovannia. Pedahohichnyi slovnyk. M. D. Yarmachenko (Ed.). Kyiv: Pedahohichna dumka [in Ukrainian].

8. Timets, O. V., Komar, V.P. (2005). Orhanizatsiia kraieznavcho-turystskoi roboty z uchnivskoiu ta studentskoiu moloddiu. Uman: Almi [in Ukrainian].

9. Fitsula, M. M. (2000). Pedahohika. Kyiv: Akademiia [in Ukrainian].

10. Yarmachenko, M. D. (2001). Patriotyzm. Pedahohichnyi slovnyk. M. D. Yarmachenko (Ed.). Kyiv: Pedahohichna dumka, 356 [in Ukrainian]. 